\title{
The combination of compost or biochar with urea and NBPT can improve nitrogen-use efficiency in maize
}

\author{
MICHELLE A. COELHO ${ }^{1}$, ROBERTA FUSCONI ${ }^{2}$, LILIANE PINHEIRO', \\ IONARA C. RAMOS ${ }^{1}$ and ADÃO S. FERREIRA ${ }^{1}$ \\ ${ }^{1}$ Instituto de Ciências Agrárias, Universidade Federal de Uberlândia, Rua Amazonas, s/n, 38400-902 Uberlândia, MG, Brazil \\ ${ }^{2}$ Geociclo Biotecnologia, Rua José Andraus, 390, 38400-340 Uberlândia, MG, Brazil
}

Manuscript received on June 4, 2017; accepted for publication on October 31, 2017

\begin{abstract}
The addition of organic residues to agricultural soils has been used as a practical alternative to improve crop quality and health. The objective of this work was to evaluate maize physiological and nutritional responses to the application of compost and biochar combined with urea $(\mathrm{N})$ and $\mathrm{N}-(\mathrm{n}$-butyl) thiophosphoric triamide (NBPT). The experiment was performed in plastic pots with $3 \mathrm{~kg}$ of soil under greenhouse conditions for 30 days. The compost and biochar were applied at the rate of 0.3 ton $\mathrm{ha}^{-1}$, using an amount of nutrient (nitrogen, phosphorus and potassium) demanded by crop growth. The physiological responses of maize were monitored by measuring the plant height, stalk diameter, leaf chlorophyll content, shoot dry weight and root dry weight. The nutritional responses of maize were assessed by using the nutrient concentration and the total nutrient assimilation by the plants. The results showed that the addition of compost or biochar did not alter the maize physiological response compared to the addition of mineral fertilizer used under the same conditions. However, a difference occurred in the maize nutritional responses to the compost and biochar amendments combined with urea and NBPT. The greatest $\mathrm{N}$ concentration in maize was observed in the treatment consisting of biochar combined with urea + NBPT. All the treatments in which compost or biochar was applied in combination with urea and NBPT presented greater total N assimilation compared to the treatment with conventional fertilization. The results of this survey showed that the combination of urea and NBPT improved the nitrogen-use efficiency of maize.
\end{abstract}

Key words: composting, pyrolysis, nitrogen uptake, N-(n-butyl) thiophosphoric triamide, nutrient assimilation.

\section{INTRODUCTION}

The addition of organic residues to agricultural soils has been used as a practical alternative to reduce environmental impacts and improve soil quality and health (Khaliq et al. 2006, Jannoura

Correspondence to: Adão de Siqueira Ferreira

E-mail: adaosferreira@yahoo.com.br et al. 2014, Zhao et al. 2016). Organic residues are also used as an additional source of nutrients for plant growth and development, and the residue quantities depend on the plant nutritional requirements (Butler et al. 2001, Larney and Hao 2007). However, the use of immature waste in agricultural soils is not recommended, with the requirement of a prior stabilization treatment, 
such as composting (compost) or the pyrolysis of biomass (biochar) (Biederman and Harpole 2013, Barrena et al. 2014, Borchard et al. 2014).

Compost is a product resulting from the biochemical transformations of organic matter by thermophilic and mesophilic microorganisms under aerobic conditions. During the composting process, a reduction occurs in the organic biomass $\left(\mathrm{CO}_{2}, \mathrm{H}_{2} \mathrm{O}, \mathrm{NH}_{3}\right)$, and this reduction produces a stabilized organic matter (mostly as humic substances) (de Guardia et al. 2010, Qian et al. 2014, Hu et al. 2016). By contrast, biochar is a carbon-rich aromatic compound produced by the pyrolysis of biomass under low oxygen conditions. Currently, studies have demonstrated that biochar, used as a soil amendment, may improve soil fertility and crop yields (Lu and Zhang 2015, Agegnehu et al. 2016, Sui et al. 2016). Both products have been reported to improve soil physical, chemical and biological attributes; however, their effects depend upon many factors, including the quantity and quality of organic matter, soil type, crop species, and environmental conditions (Biederman and Harpole 2013, Borchard et al. 2014, Jannoura et al. 2014, Qian et al. 2014).

Nitrogen (N) is commonly applied to increase crop yields in agricultural soils. However, N losses may exceed 30\% in tropical soils. Adding $\mathrm{N}$ combined with compost or biochar could be an alternative strategy to avoid the loss of this nutrient (Keller 1988, Harrison and Webb 2001, Di et al. 2007). Studies have shown a positive effect on crop productivity when compost and biochar have been applied in combination with inorganic fertilizers (Steiner et al. 2007, Biederman and Harpole 2013). In contrast to mineral fertilizers, organomineral fertilizers usually release nutrients slowly. Thus, organomineral fertilizers are added to soil in relatively high quantities to achieve the same efficiency regarding plant growth and development as that achieved by mineral fertilizers. Another practice used in tropical soils is the addition of urease inhibitors, such as N-(nbutyl) thiophosphoric triamide (NBPT), to urea to reduce $\mathrm{NH}_{3}$ volatilization (Manunza et al. 1999, Zaman and Blennerhassett 2010, Zaman et al. 2013). However, the use of urea in combination with compost or biochar has yet to be reported, even though this type of agricultural practice may be important to increase the plant $\mathrm{N}$ uptake and improve the plant nutritional status.

In Brazil, maize (Zea mays L.) is an important cereal crop, with a planted area ranging from 10,000 to 15,000 million hectares (CONAB 2015). A high grain yield in maize requires adequate levels of fertilization with nitrogen, phosphorus and potassium (Ferreira et al. 2013). Alternatives for decreasing the cost to farmers using $\mathrm{N}$ fertilizers have been researched in tropical soils (Ferreira et al. 2013). In the present study, the objective was to evaluate the physiological and nutritional responses of maize to soil additions consisting of compost and biochar combined with urea and NBPT.

\section{MATERIALS AND METHODS}

\section{SOIL SAMPLING AND CHARACTERIZATION}

Soil was sampled in an area $\left(18^{\circ} 57^{\prime} 00^{\prime \prime} \mathrm{S}\right.$ and $48^{\circ} 12$ ' $\left.21^{\prime \prime} \mathrm{W}\right)$ belonging to the Institute of Agricultural Sciences of the Federal University of Uberlândia, in the southwest of Brazil. The soil samples were collected at a $10 \mathrm{~cm}$ depth in April 2015 and classified as Typic Acrustox according to Soil Taxonomy (USDA 1992). The soil was brought to the laboratory, then, sieved to $2 \mathrm{~mm}$ and dried under air temperature conditions. The soil is a type of clay that contains $57 \%$ clay, $33 \%$ sand and $10 \%$ silt. The soil chemical analysis showed the following characterization: $\mathrm{pH}$ in water, 5.2; available phosphorus, $25.7 \mathrm{mg} \mathrm{dm}^{-3}$; available potassium, $112 \mathrm{mg} \mathrm{dm}^{-3}$; exchange calcium, 0.6 $\mathrm{cmol}_{\mathrm{c}} \mathrm{dm}^{-3}$; exchange magnesium, $3.10 \mathrm{cmol}_{\mathrm{c}} \mathrm{dm}^{-3}$; exchange aluminum, $2.39 \mathrm{cmol}_{\mathrm{c}} \mathrm{dm}^{-3}$. 
COMPOST AND BIOCHAR PRODUCTION AND CHARACTERIZATION

A sugarcane filter cake from the industrial process of ethanol production was used in the processes of composting and pyrolysis. All the production processing of both compost and biochar was performed by Geociclo Biotechnology Company (http//:www.geociclo.com.br). The compost was produced by aerobic composting, with nutrient additions and moisture controlled over a period of 35 days. The aerobic composting involved mesophilic, thermophilic and stable phases. The biochar was produced from filter cake waste with $10 \%$ moisture, crushed and sieved to $<2 \mathrm{~mm}$. A slow-pyrolysis process was used to produce the biochar at a temperature of $450{ }^{\circ} \mathrm{C}$ under lowoxygen conditions. A chemical characterization was performed on both final products (Table I).

\section{PRODUCTION OF MINERAL AND ORGANIC} PELLET

This research produced seven types of fertilizers with different formulations combined in a pellet: (1) a triple super mineral fertilizer containing $6 \%$ nitrogen $(\mathrm{N}), 30 \%$ phosphorus and $10 \%$ potassium; (2) compost containing the same nutrient composition; (3) biochar containing the same nutrient composition; (4) compost containing $24 \% \mathrm{~N}$; (5) biochar containing $24 \% \mathrm{~N}$; (6) compost containing 24\% nitrogen and $0.15 \%$ NBPT; and (7) biochar containing $24 \% \mathrm{~N}$ and $0.15 \% \mathrm{NBPT}$. For each formulation, the pellets were mixed to a soluble organic polymer $(0.12 \%)$ in water. The nitrogen, phosphorus and potassium were applied as urea (Heringer, Brazil), $\mathrm{P}_{2} \mathrm{O}_{5}$ (Heringer, Brazil) and $\mathrm{KCl}$ (Heringer, Brazil) in amounts corresponding of $248 \mathrm{~N} \mathrm{~g}, 104 \mathrm{~g} \mathrm{P}$ and $68 \mathrm{~g} \mathrm{~kg}^{-1}$ organic material (compost and biochar).

\section{EXPERIMENTAL ASSAY IN GREENHOUSE AND ANALYSIS}

The experiment was performed under greenhouse conditions in plastic pots $(3.5 \mathrm{~L})$ containing $3 \mathrm{~kg}$ of soil, in four replicates. The following treatments comprised the experiment: 1- Mineral fertilizer; 2Biochar; 3- Compost; 4- Biochar + N (as urea); 5-Compost $+\mathrm{N}$; 6- Biochar $+\mathrm{N}+\mathrm{NBPT}$; 7Compost $+\mathrm{N}+\mathrm{NBPT}$; and 8- Mineral fertilizer $+\mathrm{N}$. Both the compost and biochar were applied at the rate of $0.400 \mathrm{~g} \mathrm{~kg}^{-1}$ soil $\left(\approx 0.3\right.$ ton ha $\left.{ }^{-1}\right)$. Each fertilizer pellet was crushed and mixed into soil. In each pot, 5 seeds of the hybrid Status Viptera 3 (Syngenta, Brazil) were sown at a depth of $2 \mathrm{~cm}$, followed by a reduction to three plants 10 days later. Each pot was watered twice a day with $200 \mathrm{~mL}$ of water for a period of 30 days. Every 5 days, the weight of the pots was checked and adjusted with water to restore the weight occurring at the start of the assay. The nitrogen was applied at coverage (15

TABLE I

Chemical properties of immature (Sugarcane filter cake), biochar and compost.

\begin{tabular}{ccccc}
\hline Property & Unit & Sugarcane filter cake & Biochar & Compost \\
\hline Moisture & $\%$ & 59.5 & 3.8 & 46.3 \\
Organic carbon & $\mathrm{g} \mathrm{kg}^{-1}$ & 310 & 225 & 229 \\
Nitrogen (N) & $\mathrm{g} \mathrm{kg}^{-1}$ & 16.5 & 18.0 & 15.8 \\
Phosphorus (P) & $\mathrm{g} \mathrm{kg}^{-1}$ & 9.4 & 17.8 & 18.4 \\
Potassium (K) & $\mathrm{g} \mathrm{kg}^{-1}$ & 3.5 & 9.7 & 11.1 \\
CEC & $\mathrm{mmol} \mathrm{kg}^{-1}$ & 296 & 225 & 393 \\
C/N ratio & $\mathrm{g} \mathrm{g}^{-1}$ & 19 & 12.5 & 14.5 \\
pH & - & 7.1 & 5.6 & 5.4 \\
\hline
\end{tabular}

$\mathrm{CEC}$, cation exchange capacity; $\mathrm{C} / \mathrm{N}$, carbon/nitrogen ratio; $\mathrm{pH}, 1: 2$ (waste: $\mathrm{CaCl}_{2}$ solution). 
days after emergence) in the amounts of $50 \mathrm{mg} \mathrm{N}$ $\mathrm{kg}^{-1}$ soil (as urea), as described above.

The following analyses were performed: plant height (PH), haste diameter (HD), leaf chlorophyll content (LCC), shoot dry weight (SDW), root dry weight (RDW), and plant nutrient contents (PNC). $\mathrm{PH}$ was measured using the highest leaf on each plant, and HD was measured with a pachymeter $(0.01 \mathrm{~mm})$. LCC (on the $30^{\text {th }}$ day after sowing) was measured on three representative plants per pot with a portable chlorophyll content meter (FALKERCFL 1030). SDW and RDW were measured after drying of the biomass at $60{ }^{\circ} \mathrm{C}$ for 48 hours. PNC $(\mathrm{N}, \mathrm{P}, \mathrm{K}, \mathrm{Ca}$ and $\mathrm{Mg}$ ) were determined after wet digestion with sulfuric acid according to Tedesco et al. (1995). The plant $\mathrm{N}$ content was determined by distillation using the same digestion method (Tedesco et al. 1995). The plant P content was measured photometrically with the molybdenum blue method (Tedesco et al. 1995). Other nutrients $(\mathrm{K}, \mathrm{Ca}$ and $\mathrm{Mg}$ ) were determined by atomic absorption spectrometry (Tedesco et al. 1995).

\section{STATISTICAL ANALYSIS}

A test for normally distributed data was performed, and normality was confirmed for all the variables via statistical analysis. Thus, the variables were submitted to analysis of variance (ANOVA) in a completely randomized design, with four replicates. The means obtained for the treatments were compared by Tukey's test using a significance level of 5\% and the software SISVAR (Ferreira 2011).

\section{RESULTS AND DISCUSSION}

The two waste treatment processes used in our survey resulted in similar nutrient contents (Table I). However, the compost showed greater water content compared to the biochar. An accumulation of nutrients occurred in the compost and biochar compared to the immature wastes. In the present work, both the compost and biochar were applied at low rates $\left(0.3\right.$ ton $\left.\mathrm{ha}^{-1}\right)$ when compared to other studies (Borchard et al. 2014, Lu and Zhang 2015, Sui et al. 2016). The use of compost and biochar combined with fertilizers may be an important strategy in large areas destined for agricultural practices. The addition of these organomineral fertilizers may decrease $\mathrm{N}$ losses and improve the $\mathrm{N}$ use efficiency of plants. Further, this strategy can slowly improve the soil physical, chemical and biological properties through annual applications of compost and biochar. This approach also addresses concerns regarding the cost associated with applying large amounts of compost and biochar to soils.

All the variables $(\mathrm{PH}, \mathrm{HD}, \mathrm{LCC}, \mathrm{SDW}$ and RDW) used to evaluate the maize physiological responses showed low coefficients of variation, except for RDW (Table II). The treatments using urea (the $\mathrm{N}$ source) significantly increased the maize physiological responses relative to the treatments without urea. When compared to the mineral fertilizer, the compost and biochar additions did not interfere with the maize physiological responses. These results show that compost and biochar combined with nutrients $(\mathrm{N}$, $\mathrm{P}$ and $\mathrm{K}$ ) can be applied to soil to support maize development. Nevertheless, previous reports showed that biochar decreased the maize response when compared to mineral fertilizer (Biederman and Harpole 2013, Borchard et al. 2014, Sui et al. 2016). However, these studies used a large quantity of biochar. Large quantities of compost or biochar can immobilize nutrients and negatively affect the maize physiological responses.

The shoot $\mathrm{N}$ content changed significantly in this experiment, as shown in figure 1a. Treatment 6 (Biochar $+\mathrm{N}+\mathrm{NBPT}$ ) presented the greatest shoot $\mathrm{N}$ content. The treatments with biochar or compost (T2 and T3) also significantly increased the shoot $\mathrm{N}$ content when compared to the treatment control (T1). The differences in $\mathrm{N}$ content found among 
TABLE II

Maize physiological response to the fertilizer, compost and biochar applications and the combination with urea and NBPT.

\begin{tabular}{|c|c|c|c|c|c|}
\hline \multirow{2}{*}{ Treatment $^{1}$} & \multirow{2}{*}{$\begin{array}{l}\text { Plant Height } \\
(\mathrm{cm})\end{array}$} & \multirow{2}{*}{$\begin{array}{l}\text { Haste diameter } \\
(\mathrm{mm})\end{array}$} & \multirow{2}{*}{ Chlorophyll } & \multicolumn{2}{|c|}{ Mass dry (g plant $\left.{ }^{-1}\right)$} \\
\hline & & & & SDW & RDW \\
\hline 1- Fertilizer & $62.2 \mathrm{~b}$ & $4.1 \mathrm{~b}$ & $24.9 \mathrm{~b}$ & $0.51 \mathrm{~b}$ & $0.50 \mathrm{abc}$ \\
\hline 2- Biochar & $60.0 \mathrm{~b}$ & $4.1 \mathrm{~b}$ & $25.3 \mathrm{~b}$ & $0.51 \mathrm{~b}$ & $0.36 \mathrm{bc}$ \\
\hline 3- Compost & $64.2 \mathrm{~b}$ & $4.6 \mathrm{~b}$ & $24.9 \mathrm{~b}$ & $0.64 \mathrm{~b}$ & $0.28 \mathrm{c}$ \\
\hline 4- Biochar $+\mathrm{N}$ & $89.7 \mathrm{a}$ & $7.0 \mathrm{a}$ & $36.9 \mathrm{a}$ & $1.77 \mathrm{a}$ & $0.63 \mathrm{ab}$ \\
\hline 5- Organic $+\mathrm{N}$ & $85.5 \mathrm{a}$ & $6.8 \mathrm{a}$ & $38.5 \mathrm{a}$ & $1.64 \mathrm{a}$ & $0.71 \mathrm{a}$ \\
\hline 6- Biochar $+\mathrm{N}+\mathrm{NBPT}$ & $86.7 \mathrm{a}$ & $7.1 \mathrm{a}$ & $39.8 \mathrm{a}$ & $1.62 \mathrm{a}$ & $0.55 \mathrm{abc}$ \\
\hline 7- Organic $+N+$ NBPT & $88.2 \mathrm{a}$ & $7.0 \mathrm{a}$ & 38.9 a & $1.76 \mathrm{a}$ & $0.74 \mathrm{a}$ \\
\hline $8-$ Fertilizer $+\mathrm{N}$ & $88.8 \mathrm{a}$ & $6.7 \mathrm{a}$ & $41.1 \mathrm{a}$ & $1.60 \mathrm{a}$ & $0.66 \mathrm{a}$ \\
\hline $\mathrm{CV}(\%)$ & 4.53 & 5.83 & 5.94 & 9.58 & 22.7 \\
\hline
\end{tabular}

${ }^{1}$ Treatments followed by similar letters do not differ by a Tukey's test at $5 \%$ significance.

SDW, shoot dry weight; RDW, root dry weight; N, nitrogen; NBPT, N-(n-butyl) thiophosphoric triamide; CV, coefficient variation.

the treatments were lower for the roots than for the shoots (Figure 1b). The treatment with biochar (T2) presented the lowest root $\mathrm{N}$ content, and the treatment with mineral fertilizer plus N (T8) presented the greatest content. This experiment showed that the application of biochar or compost positively affected maize nutritional responses.

The current work additionally calculated the total $\mathrm{N}$ assimilation per plant in shoots (Figure 2a) and in roots (Figure 2b). The results showed a significant increase of $\mathrm{N}$ in the treatments with urea compared to the treatments without urea. An effect on the total $\mathrm{N}$ assimilation in plant shoots occurred when either biochar or compost was combined with urea and NBPT (Figure 2a). The total $\mathrm{N}$ assimilation in plant shoots was greater for biochar or compost combined with N and NBPT compared to mineral fertilizer combined with $\mathrm{N}$ (T8). However, for neither the treatments with biochar nor those with compost did a difference exist between those with and without added NBPT. In roots, no difference was detected between the treatments with the urea and NBPT additions. The addition of neither biochar (T2) nor compost (T3) affected the total $\mathrm{N}$ assimilation in roots compared to the addition of fertilizer (T1) (Figure 2). The total
$\mathrm{N}$ assimilation by plants is an important indicator of their nutritional response because this assimilation represents the $\mathrm{N}$ accumulation during the plant growth period under specific conditions. Here, maize was used as a model to assess the biochar and compost amendments to soil. Maize grows well under greenhouse conditions and defines its potential yield by 30 days after planting (Ritchie et al. 1991).

In the present experiment, the results showed a similar maize response to the application of biochar compared to compost when these amendments were combined with nitrogen. This shows that both organic matter products have the same efficiency regarding maize responsiveness. This efficiency can be linked for both products to reduce the $\mathrm{N}$ losses. However, the mechanisms involved in reducing $\mathrm{N}$ losses can differ due to the specific characterization of the biochar or compost applied in combination with urea. Biochar is dominantly composed of aromatic compounds, which are resistant to biological degradation (Baldock and Smernik 2002, Abujabhah et al. 2015, Lu and Zhang 2015). The aromatic structures of biochar can be important to reduce the $\mathrm{N}$ losses and increase the $\mathrm{N}$ availability in agricultural soils (Abujabhah et al. 

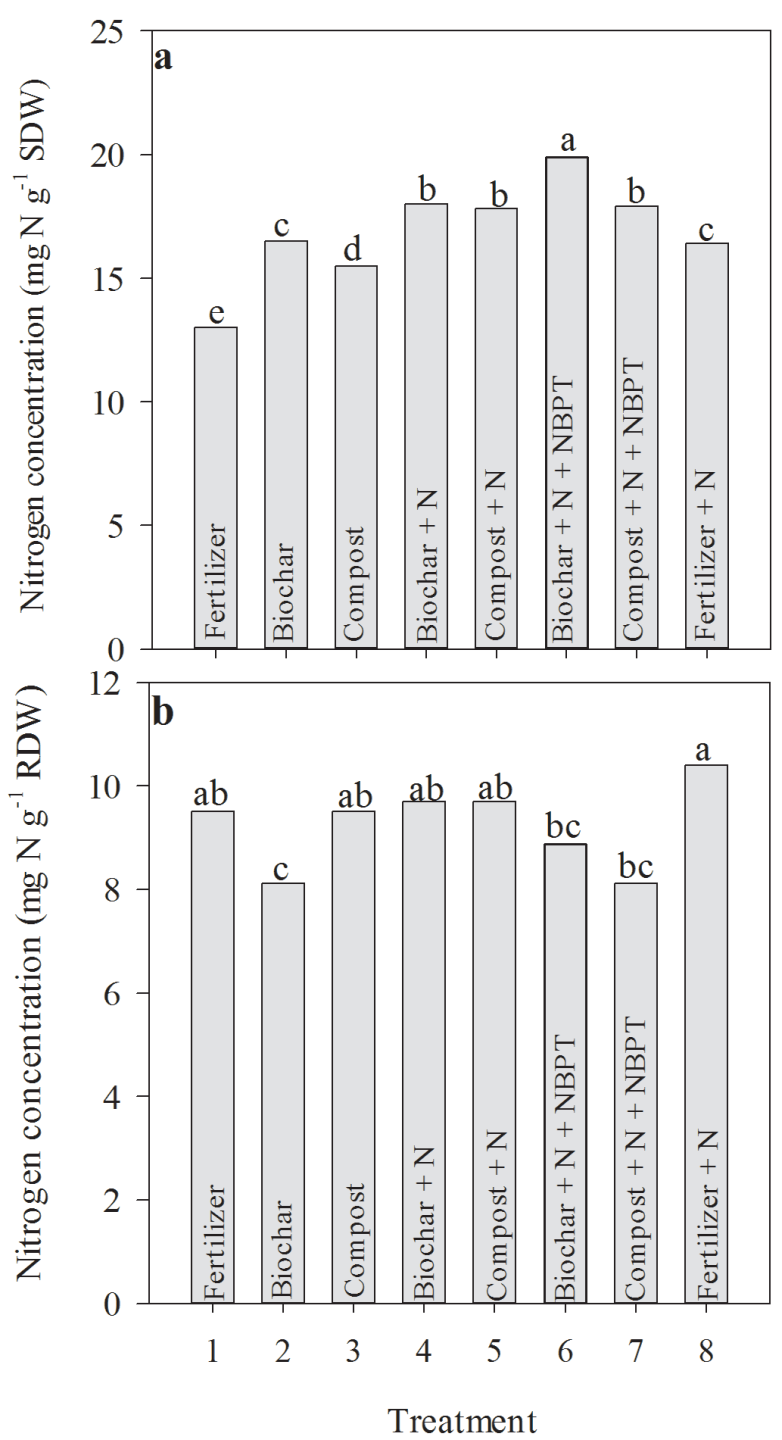

Figure 1 - Nitrogen concentration in shoots (a) and roots (b) in response to the addition of compost and biochar combined with $\mathrm{N}$ and urease inhibitor: 1- Fertilizer; 2- Biochar; 3- Compost; 4- Biochar + N; 5- Compost + N; 6- Biochar + N + NBPT; 7- Compost $+\mathrm{N}+\mathrm{NBPT}$; and 8- Fertilizer $+\mathrm{N}$. Treatments followed by similar letters do not differ by Tukey's test at the $5 \%$ significance level.

2015, Case et al. 2015, Sui et al. 2016). Composts have a high content of humic substances, and their use as soil amendments can increase the cation exchange capacity (Abujabhah et al. 2015, Case et al. 2015, Thuille et al. 2015). Both biochar and compost may decrease soil $\mathrm{NH}_{3}$ volatilization and increase $\mathrm{N}$ availability for plant growth.
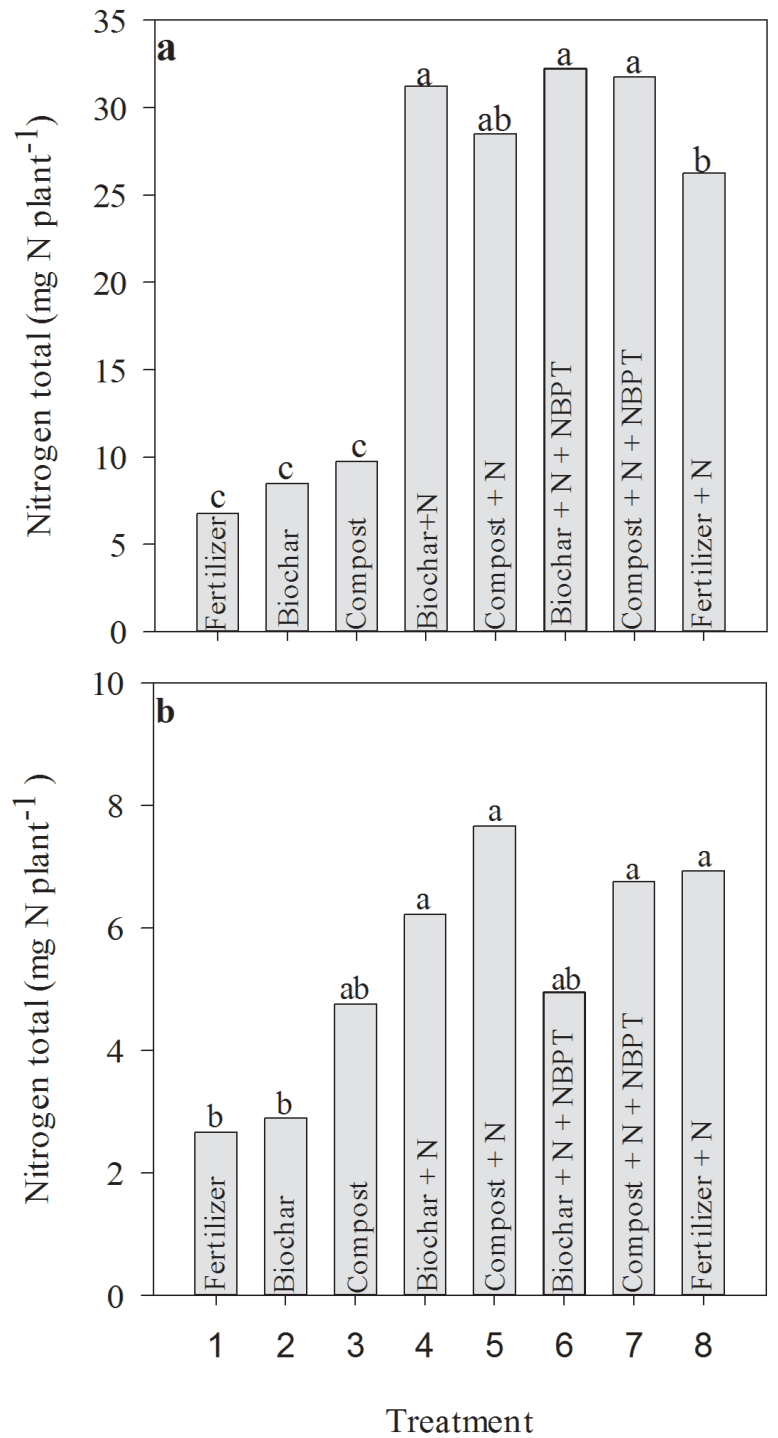

Figure 2 - Total $\mathrm{N}$ assimilation per plant in shoots (a) and roots (b) in response to the addition of compost and biochar combined with $\mathrm{N}$ and urease inhibitor: 1- Fertilizer; 2- Biochar; 3- Compost; 4- Biochar $+\mathrm{N}$; 5- Compost $+\mathrm{N}$; 6-Biochar + $\mathrm{N}+\mathrm{NBPT}$; 7- Compost $+\mathrm{N}+\mathrm{NBPT}$; and 8- Fertilizer $+\mathrm{N}$. Treatments followed by similar letters do not differ by Tukey's test at the $5 \%$ significance level.

Other nutrients ( $\mathrm{P}, \mathrm{K}, \mathrm{Ca}$ and $\mathrm{Mg}$ ) were determined to evaluate the total nutrient assimilation by plants (Table III). The treatment with fertilizer + $\mathrm{N}$ (T8) presented the greatest $\mathrm{P}$ values in shoots and roots. In general, our results showed that biochar and compost decreased the total $\mathrm{P}$ assimilation by plants. The same amount of $\mathrm{P}$ was applied in 
TABLE III

Total nutrient assimilation in maize to soil fertilizer, compost and biochar additions combined with urea and NBPT.

\begin{tabular}{|c|c|c|c|c|}
\hline \multirow{2}{*}{ Treatment $^{1}$} & \multicolumn{4}{|c|}{ Nutrient content $\left(\right.$ g plant $\left.^{-1}\right)$} \\
\hline & $\mathrm{P}$ & $\mathrm{K}$ & $\mathrm{Ca}$ & $\mathrm{Mg}$ \\
\hline & \multicolumn{4}{|c|}{ Shoot } \\
\hline 1- Fertilizer & $1.08 \mathrm{~d}$ & $19.5 \mathrm{~b}$ & $7.04 \mathrm{~b}$ & $1.40 \mathrm{c}$ \\
\hline 2- Biochar & $1.09 \mathrm{~d}$ & $19.4 \mathrm{~b}$ & $8.31 \mathrm{~b}$ & $1.51 \mathrm{c}$ \\
\hline 3-Compost & $1.42 \mathrm{~d}$ & $23.3 \mathrm{~b}$ & $9.28 \mathrm{~b}$ & $1.82 \mathrm{c}$ \\
\hline 4- Biochar $+\mathrm{N}$ & $3.45 \mathrm{ab}$ & $62.3 \mathrm{a}$ & $25.5 \mathrm{a}$ & $4.99 \mathrm{a}$ \\
\hline 5- Compost $+\mathrm{N}$ & $2.82 \mathrm{c}$ & $57.7 \mathrm{a}$ & $24.4 \mathrm{a}$ & $4.34 \mathrm{~b}$ \\
\hline 6- Biochar $+\mathrm{N}+\mathrm{NBPT}$ & $3.27 \mathrm{~b}$ & 58.9 a & $24.9 \mathrm{a}$ & $4.64 \mathrm{ab}$ \\
\hline 7- Compost $+\mathrm{N}+\mathrm{NBPT}$ & $3.29 \mathrm{~b}$ & $61.9 \mathrm{a}$ & $25.3 \mathrm{a}$ & $4.70 \mathrm{a}$ \\
\hline $8-$ Fertilizer $+\mathrm{N}$ & $3.79 \mathrm{a}$ & $54.6 \mathrm{a}$ & $21.9 \mathrm{a}$ & $4.32 \mathrm{~b}$ \\
\hline \multirow[t]{2}{*}{$\mathrm{CV}(\%)$} & 5.9 & 2.0 & 4.7 & 4.9 \\
\hline & \multicolumn{4}{|c|}{ Root } \\
\hline 1- Fertilizer & $0.45 \mathrm{c}$ & $7.50 \mathrm{~b}$ & $4.06 \mathrm{c}$ & $0.68 b$ \\
\hline 2- Biochar & $0.22 \mathrm{~d}$ & $2.98 \mathrm{c}$ & $3.51 \mathrm{~cd}$ & $0.49 \mathrm{c}$ \\
\hline 3- Compost & $0.18 \mathrm{~d}$ & $3.85 \mathrm{c}$ & $2.83 \mathrm{~d}$ & $0.38 \mathrm{c}$ \\
\hline 4- Biochar $+\mathrm{N}$ & $0.47 \mathrm{c}$ & $9.95 \mathrm{~b}$ & $5.67 \mathrm{~b}$ & $0.97 \mathrm{ab}$ \\
\hline 5- Compost $+\mathrm{N}$ & $0.53 \mathrm{bc}$ & $11.6 \mathrm{ab}$ & $5.92 \mathrm{~b}$ & $1.15 \mathrm{a}$ \\
\hline 6- Biochar + N + NBPT & $0.39 \mathrm{c}$ & $7.86 \mathrm{~b}$ & $5.29 \mathrm{~b}$ & $0.80 \mathrm{~b}$ \\
\hline 7- Compost $+\mathrm{N}+\mathrm{NBPT}$ & $0.56 \mathrm{ab}$ & $12.6 \mathrm{a}$ & $6.91 \mathrm{a}$ & $1.07 \mathrm{a}$ \\
\hline 8- Fertilizer $+\mathrm{N}$ & $0.66 \mathrm{a}$ & $13.1 \mathrm{a}$ & $5.44 \mathrm{~b}$ & $1.19 \mathrm{a}$ \\
\hline $\mathrm{CV}(\%)$ & 8.1 & 5.9 & 7.9 & 7.4 \\
\hline
\end{tabular}

${ }^{1}$ Treatments followed by similar letters do not differ by a Tukey's test at $5 \%$ significance for each nutrient. N, nitrogen; P, phosphorus; K, potassium; Ca, calcium; $\mathrm{Mg}$, magnesium; NBPT, $\mathrm{N}$-(n-butyl) thiophosphoric triamide; CV, coefficient variation.

all the experimental treatments. This reduction may have occurred because of the adsorption of P to the matrix of biochar (Abujabhah et al. 2015, Takaya et al. 2016) and compost as well as the immobilization of this nutrient in the microbial biomass (Takaya et al. 2016). Previous studies have shown that biochar and compost increased the microbial activity (Jannoura et al. 2014, Abujabhah et al. 2015). Additional nutrients ( $\mathrm{K}, \mathrm{Ca}$ and $\mathrm{Mg}$ ) in the shoot were not affected by the biochar or compost application when compared to the other treatments with the same fertilization conditions, except for the treatments with biochar $+\mathrm{N}$ (T4) and biochar $+\mathrm{N}+$ NBPT (T7) that presented the greatest $\mathrm{Mg}$ values. However, more studies should be performed to better characterize the impact of the biochar and compost amendments on these nutrients.

\section{CONCLUSIONS}

The present work revealed important effects of biochar and compost used as a soil amendment in combination with urea and NBPT on maize physiological and nutritional responses under greenhouse conditions. Our results showed that the addition of biochar or compost did not alter the maize physiological response compared to that produced by the addition of mineral fertilizer under the same conditions. No difference regarding the physiological response of maize existed between the biochar and compost soil amendments. 
However, there was difference in maize nutritional responses to biochar and compost amendments combined with urea and NBPT. The greatest $\mathrm{N}$ content in maize shoots was observed in the treatment involving biochar combined with urea + NBPT. The addition of either biochar or compost combined with urea and NBPT presented a greater total $\mathrm{N}$ assimilation compared to the addition of mineral fertilizer. The use of biochar or organic compost from industrial residues, such as sugarcane filter cake, when combined with urea in a pelletized organomineral fertilizer, may be an important practice to improve the nitrogen-use efficiency of cereal crops in tropical soils.

\section{REFERENCES}

ABUJABHAH IS, BOUND SA, DOYLE R AND BOWMAN JP. 2015. Effects of biochar and compost amendments on soil physico-chemical properties and the total community within a temperature agricultural soil. Appl Soil Ecol 98: 243-253.

AGEGNEHU G, BASS AM, NELSON PN AND BIRD MI. 2016. Benefits of biochar, compost and biochar-compost for soil quality, maize yield and greenhouse gas emissions in a tropical agricultural soil. Sci Environ 543: 295-306.

BALDOCK JA AND SMERNIK RJ. 2002. Chemical composition and bioavailability of thermally, altered Pinus resinosa (Red Pine) wood. Org Geochem 33: 1093-1109.

BARRENA R, FONT X, GABARREL X AND SÁNCHEZ A. 2014. Home composting versus industrial composting: Influence of composting system on compost with focus on compost stability. Waste Manage 34: 1109-1116.

BIEDERMAN LA AND HARPOLE WS. 2013. Biochar and its effects on plant productivity and nutrient cycling: a meta-analysis Glob. Change Biol Bioenergy 5: 202-214.

BORCHARD N, SIEMENS J, LADD B, MÖLLER A AND AMELUNG W. 2014. Application of bichars to sandy and silty soil failed to increase maize yield under common agricultural practice. Soil Till Res 144: 184-194.

BUTLER TA, SIKORA LJ, STEINHILBER PM AND DOUGLASS LW. 2001. Compost age and sample storage effects on maturity indicators of biosolids compost. J Environ Qual 30: 2141-2148.

CASE SDC, MCNAMARA NP, REAY DS, STOTT AW, GRANT HK AND WHITAKER J. 2015. Biochar suppresses $\mathrm{N}_{2} \mathrm{O}$ emissions while maintaining $\mathrm{N}$ availability in a sandy loam soil. Soil Biol Biochem 81: 178-185.
CONAB. 2015. Companhia Nacional de Abastecimento. Available at: http://www.conab.gov.br/conabweb/ download/safra/BrasilProdutoSerielHost.sls.

DE GUARDIA A, MALLARD P, TEGLIA C, MARIN A, LE PAPE C, LAUNAY M, BENOIST JC AND PETIOT C. 2010. Comparison of five organic wastes regarding their behavior during composting: part 1, biodegradability, stabilization kinetics and temperature rise. Waste Manage 30: 402-414.

DI HJ, CAMERON KC AND SHERLOCK RR. 2007. Comparison of the effectiveness of a nitrification inhibitor, dicyandiamide, in reducing nitrous oxide emissions in four different soils under different climatic and management conditions. Soil Use Manage 23: 1-9.

FERREIRA AS, PIRES RR, RABELO PG, OLIVEIRA RC, LUZ JMQ AND BRITO CH. 2013. Implications of Azospirillum brasilense inoculation and nutrient addition on maize in soils of the Brazilian Cerrado under greenhouse and field conditions. Appl Soil Ecol 72: 3-108.

FERREIRA DF. 2011. Sisvar: a computer statistical analysis system. Ci Agrotecnol 35: 1039-1042.

HARRISON R AND WEBB J. 2001. A review of the effect of $\mathrm{N}$ fertilizer type on gaseous emissions. Adv Agron 73: 65-108.

HU X ET AL. 2016. Asynchronous responses of soil carbon dioxide, nitrous oxide emissions and net nitrogen mineralization to enhanced fine root input. Soil Biol Biochem 92: 67-78.

JANNOURA R, JOEGENSEN RG AND BRUNS C. 2014. Organic fertilizer effects on growth, crop yield, and soil microbial biomass indices in sole and intercropped peas and oats under organic farming conditions. Eur J Agron 52: $259-270$.

KELLER M. 1988. Emissions of $\mathrm{N}_{2} \mathrm{O}$ from tropical forest soils: responses to fertilization with $\mathrm{NH}_{4}^{+}, \mathrm{NO}_{3}^{-}$, and $\mathrm{PO}_{4}^{3-}$. J Geophys Res 93: 1600-1604.

KHALIQ A, ABBASI MK AND HUSSAIN T. 2006. Effects of integrated use of organic and inorganic nutrient sources with effective microorganisms (EM) on seed cotton yield in Pakistan. Bioresour Technol 97: 967-972.

LARNEY FJ AND HAO X. 2007. A review of composting as a management alternative for beef cattle feedlot manure in Alberta, Canada. Bioresour Technol 98: 3221-3227.

LU W AND ZHANG H. 2015. Response of biochar induced carbon mineralization priming effects to additional nitrogen in a sandy loam soil. Appl Soil Ecol 96: 165-171.

MANUNZA B, DEIANA S, PINTORE M AND GESSA C. 1999. The binding mechanism of urea, hydroxamic acid and $\mathrm{N}-(\mathrm{N}$-butyl)- phosphoric triamide to the urease active site. A comparative molecular dynamics study. Soil Biol Biochem 31: 789-796.

QIAN X, SHEN G, WANG Z, GUO C, LIU Y, LEI Z AND ZHANG Z. 2014. Co-composting of livestock manure 
with rice straw: Characterization and establishment of maturity evaluation system. Waste Manage 34: 530-535.

RITCHIE SW, HANWAY J AND BENSON GO. 1991. How a corn plant develops. Ames: Iowa State University of Science and Technology, (Special report, 48), $26 \mathrm{p}$.

STEINER C, BLUM WEH, ZECH W, DE MARCELO JLV, TEIXEIRA WG, LEHMANN J AND NEHLS T. 2007. Long term effects of manure, charcoal and mineral fertilization on crop production and fertility on a highly weathered Central Amazonian upland soil. Plant Soil 291: 275-290.

SUI Y, GAO J, LIU C, ZHANG W, LAN Y, LI S, MENG J, XU Z AND TANG L. 2016. Interactive effects of strawderived biochar and $\mathrm{N}$ fertilization on soil $\mathrm{C}$ storage and rice productivity in rice paddies of Northeast China. Sci Environ 544: 203-210.

TAKAYA CA, FLETCHER LA, SINGH S, ANYIKUDE KU AND ROSS AB. 2016. Phosphate and ammonium sorption capacity of biochar and hydrochar from different wastes. Chemosphere 145: 518-527.

TEDESCO MJ, BOHNEM H, GIANELLO C, BISSANI CA AND VOLKWEISS SJ. 1995. Análise de solo, plantas e outros materiais. UFRGS, Porto Alegre, Rio Grande do Sul, 174 p.
THUILLE A, LAUFER J, HÖHL C AND GLEIXNER G. 2015. Carbon quality affects the nitrogen partitioning between plants and soil microorganisms. Soil Biol Biochem 81: 266-274.

USDA. 1992. USDA, Soil Conservation Service. Soil Taxonomy: A basic system of soil classification for making and interpreting soil surveys. Agricultural Handbook 436. USDA, Washington, DC, $869 \mathrm{p}$.

ZAMAN M AND BLENNERHASSETT JD. 2010. Effects of the different rates of urease and nitrification inhibitors on gaseous emissions of ammonia and nitrous oxide, nitrate leaching and pasture production from urine patches in an intensive grazed pasture system. Agric Ecosyst Environ 136: 236-246.

ZAMAN M, DEIANA S, PINTORE M AND GESSA C. 2013. Effects of urease and nitrification inhibitors on the efficient use of urea for pastoral systems. Soil Sci Plant Nutri 59: 649-659.

ZHAO J, NI T, LI J, LU Q, FANG Z, HUANG Q, ZHANG R, LI R, SHEN B AND SHEN Q. 2016. Effects of organicinorganic compound fertilizer with reduced chemical fertilizer application on crop yields, soil biological activity and bacterial community structure in a rice-wheat cropping system. Appl Soil Ecol 99: 1-12. 